\title{
Competition of biological agents of Streptomyces sp, Gliocladium sp, and Trichoderma harzianum to Fusarium oxysporum in Tomato Rhizophere
}

\author{
Penta Suryaminarsih*, Tri Mujoko \\ Department of Agrotechnology, Faculty of Agriculture, Pembangunan Nasional "Veteran" University, Surabaya, \\ East Java, Indonesia, 60294 \\ *Corresponding Author: penta_s@upnjatim.ac.id
}

Received November 01, 2019; revised November 04, 2019; accepted June 30, 2020

\begin{abstract}
Fusarium oxysporum is a soil-borne fungus that attacks all stages of tomato plant from seedlings to mature plants. The disease occurrence on the tomato nursery can lead economically loss due to its fast and massive damage. Application of effective biological control agents is considered as promising control measure of the disease. The aim of this study was to evaluate the potential competitiveness of biological agents mixture consisting of Streptomyces sp., Gliocladium sp. and T. harzianum against $F$. oxysporum f. sp. lycopersici in the rhizosphere of the tomato plant. The experiment was arranged in completely randomized design with five treatment types of agents that a single biological agents Streptomyces sp. (S), a mixture of Streptomyces sp. and Gliocladium sp. (SG), a mixture of Streptomyces sp. and T. harzianum (ST), a mixture of Streptomyces sp., Gliocladium sp., and T. harzianum (SGT) and control without biological agents. Each treatment was replicated four times and consisted of 6 plants for observation purposes destructively. Descriptive analysis conducted on the pattern of colonization of the roots competition showed a growth pattern colonization of biological agents, Streptomyces sp, Gliocladium sp, $T$. harzianum and F. oxysporum pathogen (SGTF) was the same growth pattern of SGF and STF, where four of the microbes grew on the same side of roots as fungal pathogens, in all parts of the root sprouts. Given biological agent Streptomyces sp, Gliocladium sp., dan Trichoderma harzianum decreased fusarium wilt diseases severity of tomato. Weight root of tomato plants was applied by biological agents was $9.2 \mathrm{~g}$ greater than plant without biological agents, which were $2.5 \mathrm{~g}$. The observation on tomato indicated root colonization occurs, especially on the base of the stem-roots by a mixture of biological agents T. harzianum and Gliocladium sp.
\end{abstract}

Keywords: colonization, roots, soil microbes, wilt

\section{Abstrak \\ Kompetisi Agens Hayati Streptomyces sp., Gliocladium sp., dan Trichoderma harzianum terahadap Fusarium oxysporum pada Akar Tanaman Tomat}

Fusarium oxysporum adalah cendawan tular tanah yang menginfeksi tanaman tomat mulai dari persemaian sampai tanaman dewasa. Infeksi pada persemaian dapat menyebabkan kerugian hasil yang nyata akibat kerusakan yang cepat dan massif. Salah satu cara pengendalian yang mendapatkan perhatian utama dari ahli hama penyakit tanaman ialah menggunakan agens pengendali hayati. Tujuan dari penelitian ini ialah menentukan potensi kompetisi campuran agens hayati (Streptomyces $\mathrm{sp}$., Gliocladium sp. dan T. harzianum) terhadap F. oxysporum f.sp. lycopersici pada rizosfer tanaman tomat. Penelitian disusun menggunakan rancangan acak lengkap yang terdiri dari 5 perlakuan jenis agens pengendali hayati, yaitu agens hayati tunggal Streptomyces sp. (S), campuran Streptomyces sp. dan Gliocladium sp. (SG), campuran Streptomyces sp. dan T. harzianum (ST), campuran Streptomyces sp., Gliocladium sp., dan T. harzianum (SGT), serta kontrol tanpa agens hayati. Setiap perlakuan diulang sebanyak 4 kali, masing masing 6 tanaman untuk pengamatan pola kolonisasi yang dilakukan secara destruktif. Analisis deskriptif menunjukkan bahwa pola pertumbuhan kolonisasi agens hayati SGT terhadap patogen $F$. oxysporum sama dengan pola pertumbuhan SG dan ST, yaitu kompetisi nutrisi. Pemberian agens hayati Streptomyces sp., Gliocladium sp., dan T. harzianum mampu menghambat perkembangan keparahan penyakit layu fusarium. Berat akar tomat yang diberi agens hayati 9.2 gram sedangkan yang tidak diberi agens hayati 2.5 gram. Hasil pengamatan pada akar tanaman tomat menunjukkan terjadi kolonisasi akar, terutama pada pangkal batang-akar oleh campuran agens hayati T. harzianum dan Gliocladium sp.

Kata kunci: kolonisasi, akar, mikroba tanah, layu

\section{PENDAHULUAN}

Fusarium oxysporum adalah cendawan penyebab penyakit layu fusarium pada tomat yang memiliki kisaran inang luas dan hidup sebagai saprob dalam tanah dengan membentuk struktur dorman yang sulit untuk dikendalikan. Patogen ini dapat menginfeksi saat persemaian sampai tanaman dewasa. Usaha pengendalian terhadap penyakit layu fusarium pada tomat umumnya menggunakan fungisida. Penggunaan mikroorganisme sebagai Agens hayati untuk pengendalian penyakit tanaman dapat mengurangi polusi racun dan lebih fleksibel dibandingkan dengan pestisida kimia. Pengendalian biologis cenderung sangat spesifik dan memiliki mekanisme yang berbeda yang meliputi, parasitisme, predator, antibiotik, persaingan untuk situs dan nutrisi, 
serta dengan mendorong resistensi pada tanaman terhadap patogen, termasuk Induced Systemic Resistance (ISR) (Kamal, et al, 2015)

Beberapa agens hayati telah diuji sebagai agens pengendalian hayati penyakit tular tanah. Streptomyces sp. dari lahan cabe dapat menghambat $F$. oxysporum dan dapat meningkatkan pertumbuhan tanaman tomat. Campuran Streptomyces griseorubens, dan Trichoderma harzianum, Gliocladium sp sebagai agens hayati lebih dapat menghambat keparahan penyakit layu fusarium dibandingkan jika sebagai agens hayati tunggal dan kontrol akan tetapi hasil campuran Streptomyces griseorubens, dan Trichoderma harzianum masih lebih dapat menekan perkembangan Fusarium oxysporum jika dibandingkan campuran 3 agens hayati (Suryaminarsih et al., 2015; Laila et al., 2016).

Streptomyces sp. efektif mendegradasi jerami rumput menjadi sumber karbon tersedia bagi tanaman dan sebagai dekomposer yang mengubah protein rekalsitran menjadi proteolisis. Selain memiliki potensi sebagai agens hayati Streptomyces sp. Juga memiliki kemampuan sebagai Plant Growth Promoting Rhizocbateria (PGPR) yang dapat memacu pertumbuhan tanaman melalui ketersediaan nutrisi di dalam tanah atau dengan memproduksi siderofor dan fitohormon asam indolasetat (IAA) (Tamreihao et al., 2016)

Unit Pelaksana Teknis Pengendalian Hayati Tanaman Perkebunan dan Hortikultura Mojosari, telah memanfaatkan Trichoderma harzianum sebagai agens hayati tunggal untuk pengendalian beberapa penyakit tular tanah tanaman perkebunan dan hortikultura secara luas. Balai Pengamat Pengendalian Hama dan Penyakit Tanaman Pangan dan Hortikultura (BPPHPTPH) di Pandaan, juga telah menggunakan $T$. harzianum dan Gliocladium sp. sebagai agens hayati tunggal untuk pengendalian penyakit tular tanah dan telah dimanfaatkan oleh petani. Penelitian ini bertujuan untuk menentukan potensi kompetisi campuran agens hayati yang terdiri atas Streptomyces sp., Gliocladium sp. dan $T$. harzianum terhadap $F$. oxysporum f.sp. lycopersici. di rizosfer tomat.

\section{BAHAN DAN METODE}

Penelitian disusun menggunakan Rancangan Acak Lengkap (RAL) dengan lima perlakuan jenis agens hayati, yaitu tunggal Streptomyces sp. (S), campuran Streptomyces sp. dan Gliocladium sp. (SG), campuran Streptomyces sp. dan T. harzianum (ST), campuran Streptomyces sp., Gliocladium sp., dan $T$. harzianum (SGT) dan kontrol tanpa agens hayati . Setiap perlakuan diulang sebanyak empat kali. Setiap perlakuan terdiri atas 6 tanaman untuk keperluan pangamatan secara destruktif. Analisis deskriptif dilakukan terhadap pola kolonisasi pada akar (kompetisi).

\section{Isolasi dan Pembuatan Suspensi Fusarium oxysporum}

Fusarium oxysporum diisolasi dari batang tomat yang menunjukkan gejala layu di Kecamatan Wajak-Malang. Bagian batang tanaman yang sakit disterilkan dengan alkohol 70\%, lalu dikeringanginkan. Batang tersebut kemudian disayat kulitnya dan bagian kulit ini diletakkan pada medium agar-agar dekstrosa kentang (ADK). Cendawan yang tumbuh diisolasi, dimurnikan, dan diremajakan pada medium ADK.

Pembuatan suspensi $F$. oxysporum dilakukan dengan cara sebagai berikut: Tiga cakram $(5 \mathrm{~mm})$ dari biakan murni $F$. oxysporum berumur 5 hari diinokulasikan ke dalam labu Erlenmeyer $250 \mathrm{~mL}$ berisi $100 \mathrm{~mL}$ air steril, untuk mendapatkan suspensi spora yang homogen, suspensi divortex dengan kecepatan tinggi selama 5 menit, kemudian dihitung massa spora menggunakan Haemocytometer hingga didapatkan suspensi yang mengandung massa spora $10^{9} \mathrm{spora} / \mathrm{mL}$.

\section{Isolasi dan Penyiapan Suspensi Agens Hayati}

Sebanyak $1 \mathrm{~g}$ tanah dari lahan cabai dan lahan tomat ditimbang lalu dibuat suspensi dengan pengenceran $10^{-4}$. Sebanyak $1 \mathrm{~mL}$ suspensi dituang ke dalam medium agar-agar gula nitrat (AGN) di cawan petri untuk mendapatkan isolat Streptomyces sp.. Isolat T.harzianum, Gliocladium sp. diperoleh dari BPPHTPH Pandaan diremajakan dan diperbanyak pada medium Potato Dextrose Agar (PDA).

Suspensi agens hayati disiapkan dengan cara melakukan pengenceran untuk memperoleh kerapatan spora yang yang hampir seragam yaitu untuk Trichoderma harzianum dan Gliocladium sp pengenceran sebelas kali $\left(10^{11}\right)$, sedangkan Streptomyces sp empat kali pengenceran $\left(10^{4}\right)$ sehingga didapatkan 38-42 spora/cc dilakukan dengan cara sebagai berikut: Dua cakram $(5 \mathrm{~mm})$ masingmasing kultur jamur Gliocladium sp. dan $T$. harzianum (berumur 7 hari) serta kultur bakteri Streptomyces sp. (berumur 14 hari) dimasukkan ke dalam $10 \mathrm{~mL}$ air steril pada tabung reaksi. Selanjutnya tabung reaksi berisi mikroorganisme tersebut divortek dengan kecepatan tinggi selama 2 menit. Masingmasing suspensi yang diperoleh disaring dengan kertas Whatman $44 \mathrm{~mm}$. Suspensi hasil saringan ini kemudian diambil $1 \mathrm{~mL}$ dan disuspensikan lagi ke dalam $9 \mathrm{~mL}$ air distilata, divorteks selama 1 menit.

Kerapatan spora jamur Gliocladium sp,dan $T$. harzianum diamati dan dihitung dengan menggunakan Haemocytometer. Kerapatan spora bakteri Streptomyces sp. diamati dengan metode tuang kocok yaitu $1 \mathrm{~mL}$ suspensi awal dimasukkan pada $9 \mathrm{~mL}$ media GNA cair $40^{\circ} \mathrm{C}$, divortek lalu dituangkan ke dalam cawan petri steril dan diinkubasikan selama 7 hari, selanjutnya dihitung jumlah spora (koloni) yang tumbuh dalam media tersebut. Kontrol adalah suspensi tanpa agens hayati (Terdaftar Paten no P00201302085). Koloni yang tumbuh setelah 
diinkubasi selama 10 hari kemudian diamati. Suspensi agens hayati yang sudah disaring menggunakan kertas Whatman $44 \mathrm{~mm}$, sebanyak $6 \mathrm{~mL}$ dilarutkan ke dalam $44 \mathrm{~mL}$ air steril. Jenis perlakuan dalam penelitian ini yaitu sebagai berikut : perlakuan tunggal masing masing agens hayati $\mathrm{G}, \mathrm{T}, \mathrm{S}$ adalah $6 \mathrm{~mL}$, kombinasi GTS masing masing $2 \mathrm{~mL}(\mathrm{G}, 2 \mathrm{~mL}+\mathrm{T}, 2$ $\mathrm{mL}+\mathrm{S}, 2 \mathrm{~mL}$ ), kombinasi GT , GS , TS masing masing dengan konsentrasi $3 \mathrm{~mL}(3 \mathrm{~mL} \mathrm{~S}+3 \mathrm{~mL})$.

\section{Inokulasi Kombinasi Agens Hayati dan Patogen pada Perkecambahan}

Benih tomat varietas Mirah direndam dalam larutan sodium hipoklorit $1 \%$ selama 20 menit lalu dicuci menggunakan air steril sebanyak tiga kali. Benih dikecambahkan pada medium malt extract agar $\left(10 \mathrm{~g} \mathrm{~L}^{-1}\right)$ dalam cawan petri dan diinkubasikan dalam keadaan gelap pada suhu $22^{\circ} \mathrm{C}$ selama 4 hari. Kecambah tomat berukuran $1 \mathrm{~cm}$ digunakan untuk perlakuan. Sebanyak $5 \mathrm{~mL}$ masing-masing suspensi agens hayati diinokulasikan pada $100 \mathrm{~g}$ tanah pasir di kotak semai. Selanjutnya, sebanyak $5 \mathrm{~mL}$ suspensi $F$. oxysporum diinokulasikan pada tanah pasir tersebut. Kecambah tanaman tomat ditanam pada tanah pasir yang telah diinokulasi agens hayati dan patogen (Olivain et al. 2006).

Pengamatan kolonisasi agens hayati dilakukan pada jaringan akar kecambah tanaman tomat pada 1, 3 , dan 5 hari setelah penanaman. Akar dicuci dari partikel tanah yang menempel dan direndam dengan $\mathrm{KOH}$ selama 60 menit, lalu dicuci dengan air steril. Akar kemudian diwarnai menggunakan laktofenol biru . Bagian akar yang sudah diwarnai diletakkan pada obyek gelas cekung berisi water agar $0.1 \%$ dan diamati menggunakan mikroskop.

\section{Inokulasi Kombinasi Agens Hayati dan Patogen pada Bibit Tanaman}

Tanah disiapkan dengan cara mencampur tanah taman dan kompos dengan perbandingan $1: 1$ diaduk sampai merata kemudian disterilkan dengan menggunakan uap air panas (dikukus), selanjutnya tanah steril tersebut dimasukkan kedalam kotak semai dan polibag. Benih tanaman tomat yang sehat, direndam air hangat $50^{\circ} \mathrm{C}$, kemudian ditanam dalam tanah taman di kotak pembenihan. Selanjutnya dilakukan penyiraman setiap hari. Setelah bibit tomat memiliki daun sempurna (14 - 21 hari) bibit siap diberi agensia hayati sesuai perlakuan.

Isolat agensia hayati diinokulasikan pada bibit tomat dengan cara perendaman: stereofoam dibuat lubang sebanyak 10 lubang, kemudian bibit tomat dimasukkan ke dalam lubang-lubang sterofoam dan diletakkan di atas petri yang sudah diberi larutan inokulum kombinasi agensia hayati sesuai dengan perlakuan yang sudah dipersiapkan. Selanjutnya bibit tersebut dipindahkan beserta tanahnya kedalam polybag 3 liter berisi tanah yang mengandung $F$. oxysporum. Penimbangan berat akar dilakukan setelah panen pertama yaitu pada 60 hari setelah tanam.

\section{HASIL DAN PEMBAHASAN}

Pola pertumbuhan hifa Streptomyces sp., Gliocladium sp., $\quad T$. harzianum dan cendawan pathogen $F$. oxysporum pada akar kecambah tomat yang diamati pada hari ke-1, 3, dan 5 yaitu Pada 1 hari setelah inokulasi (HSI) belum terlihat hifa $F$. oxysporum pada akar kecambah. Hifa cendawan patogen baru tumbuh pada 3 HSI dimulai dari bagian tepi akar dan tumbuh semakin banyak sampai 5 HSI (Gambar 1).

Pada 1 HSI tampak hifa $F$. oxysporum (hifa berukuran lebih besar dan berwarna lebih gelap) mulai membentuk koloni pada bagian akar perkecambahan tomat dan dikelilingi oleh hifa Gliocladium sp.. Pada 3 dan 5 HSI hifa Gliocladium sp. semakin banyak menutupi akar kecambah, namun hifa $F$. oxysporum juga tumbuh pada sisi yang sama. Pola pertumbuhan kolonisasi agens hayati Streptomyces sp., Gliocladium sp., T. harzianum dan patogen $F$. oxysporum (SGTF) sama dengan pola pertumbuhan SGF dan STF. Empat mikroba tersebut tumbuh dan berkembang pada sisi akar yang sama dengan cendawan patogen (Gambar 2).
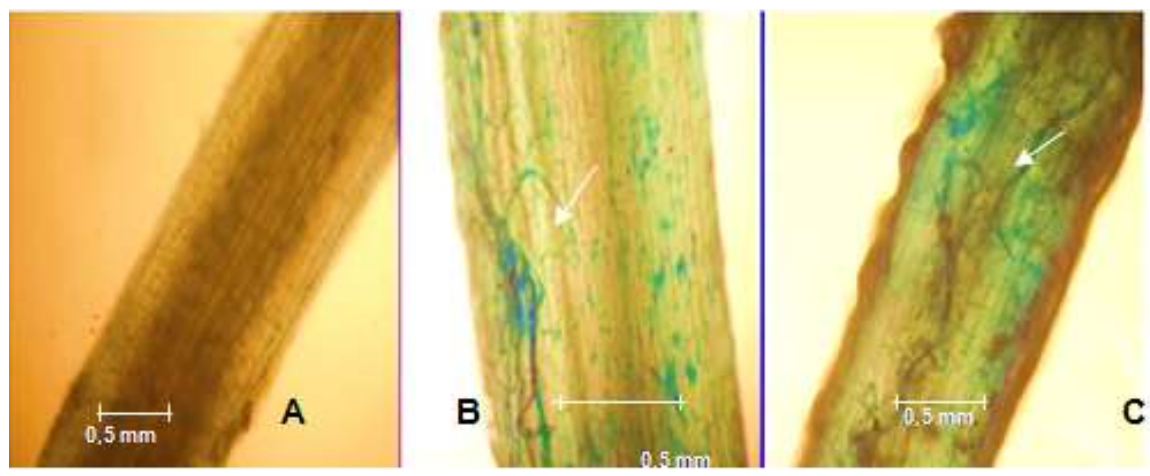

Gambar 1 Koloni cendawan patogen $F$. oxysporum pada akar kecambah tomat (tanda panah).

A. 1 hari setelah inokulasi (HSI), B. 3 HIS, dan C. 5 HSI. 


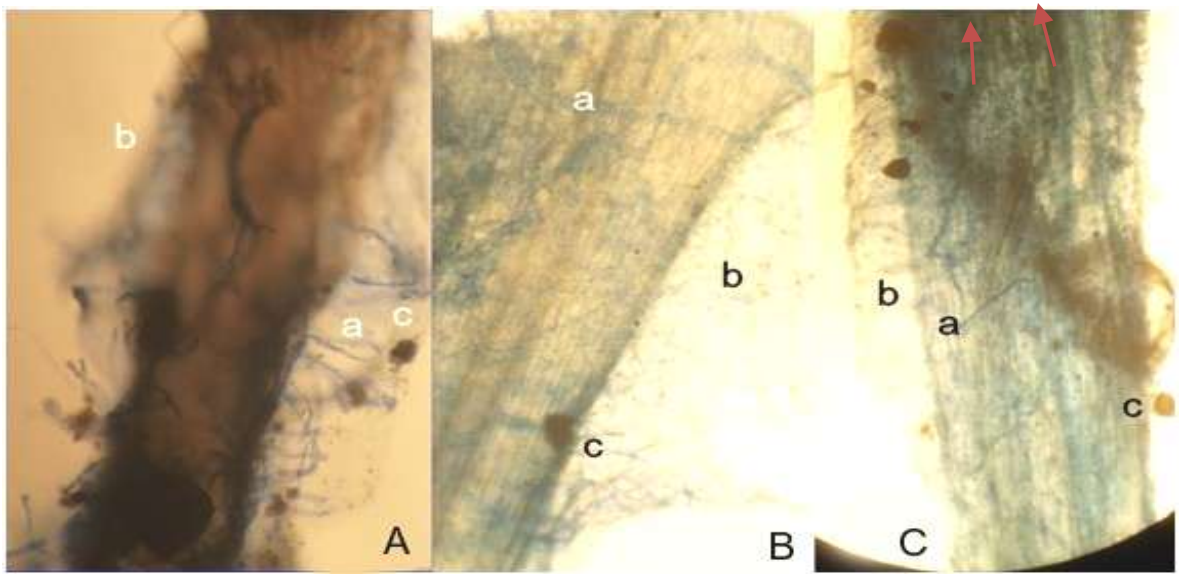

Gambar 2. Kolonisasi agens hayati Streptomyces sp., $\quad$ T. harzianum, Gliocladium sp. dan jamur patogen $F$. oxysporum pada akar kecambah tomat (Perbesaran 15x40). A. 1 hari setelah inokulasi (HIS), B. 3 HSI, C.5 HSI; a. hifa Fusarium sp. b. hifa T. harzianum, c. koloni S. griseorubens.

Bobot akar tanaman tomat yang diberi agens hayati lebih tinggi dibandingkan dengan tanpa agens hayati. Pemberian Gliocladium sp. dan T. harzianum (GT) menunjukkan berat akar tertinggi dibandingkan pemberian Streptomyces sp. (S) dan campuran ketiga agens hayati (SGT) (Tabel 1).

Kompetisi antara agens hayati dan cendawan patogen merupakan kompetisi sumber nutrisi karena $F$. oxysporum tumbuh dan berkembang pada bagian sisi akar yang sama dengan agens hayati $T$. harzianum dan Gliocladium sp.. Beberapa penelitian menemukan bahwa $T$. harzianum dan $G$. virens merupakan cendawan saprofit tanah yang dapat berkembang dengan cepat. Dalam waktu 48 jam kedua agens hayati telah dapat membentuk koloni yang membelit akar dan mengadakan penetrasi pada interselluler akar tanaman (Anitha \& Rabeeth 2009; Larkin \& Fravel, 1998; Akladious \& Abbas, 2012).

Hasil penelitian in vitro yang dilakukan juga menunjukkan bahwa kedua agens hayati tersebut adalah agens hayati yang cepat perkembangannya dan mampu menghambat perkembangan koloni $F$. oxysporum (Suryaminarsih et al., 2015). Olivain et al. (2006) menyatakan bahwa kompetisi yang terjadi antara Fusarium patogenik dan non patogenik ialah kompetisi nutrisi. Streptomyces sp. memiliki kemampuan anticendawan sehingga tidak ada kompetisi ruang dan makanan di antara patogen dan agens hayati. Hal ini karena $S$. griseorubens merupakan kelompok aktinomisetes yang menghasilkan antibiotik namun pertumbuhannya lambat. Aplikasi Streptomyces sp., T. harzianum dan $G$. virens dengan $F$. oxysporum pada tanaman tomat dapat menghambat keparahan penyakit dibandingkan kontrol. Keparahan penyakit layu fusarium tanpa pemberian agens hayati mencapai. $44,12 \%$ sedangkan dengan pemberian agens hayati $14,29 \%$, (Suryaminarsih et al., 2015).

Tabel 1. Bobot akar tanaman tomat (60 hari setelah tanam) dengan pemberian agens hayati dan $F$. oxysporum

\begin{tabular}{lc}
\hline \multicolumn{1}{c}{ Perlakuan } & Bobot segar akar (g) \\
\hline Kontrol (tanpa agens hayati)) & $(2,00 \pm 0,29) \mathrm{a}$ \\
Streptomyces sp.dan Gliocladium sp. (SG) & $(9,06 \pm 0,35) \mathrm{b}$ \\
Streptomyces sp.dan T. harzianum (ST) & $(12,5 \pm 0,33) \mathrm{b}$ \\
Streptomyces sp. (S) & $(12,81 \pm 0,35) \mathrm{c}$ \\
Streptomyces sp., Gliocladium sp., T. & $(14,04 \pm 0,38 \mathrm{c}$ \\
harzianuim (SGT) & $(14,68 \pm 0,33) \mathrm{d}$ \\
Gliocladium sp. dan T. harzianum (GT) &
\end{tabular}

Keterangan: huruf yang berbeda pada data menunjukkan berbeda nyata pada taraf uji BNJ $5 \%=0.751$

Agens hayati yang diberikan pada akar tomat menginduksi terbentuknya cabang akar baru dan membentuk akar baru pada bagian akar yang mengalami nekrosis akibat infeksi $F$. oxysporum sehingga bobot akarnya lebih tinggi. Disamping itu, $T$. harzianum dan $G$. virens dapat menginduksi terbentuknya akar samping (perifer) dan menginduksi reaksi hipersensitif yang kemudian membentuk akar baru, karena adanya enzim atau protein (Suryaminarsih et al. 2015). T. harzianum menghasilkan indole-3-acetic acid (IAA) yang menginduksi terbentuknya akar lateral. Pemberian filtrat metabolit $T$. harzianum dan pemberian agens hayati tersebut pada tanah dapat meningkatkan 
kandungan IAA dan bobot kering akar (Yedidia et al. 1999; Akladious \& Abbas 2012). T. harzianum juga menhasilkan etilen dan sitokinin (Martinez-Medina, et al., 2014). Streptomyces merupakan salah satu komponen utama penyusun populasi mikroba di lapisan rizosfer. Streptomyces memiliki kemampuan sebagai Plant Growth Promoting Rhizobacteria (PGPR) karena mampu memicu pertumbuhan tanaman melalui produksi indole-3-acetid acid (IAA) yang berperan dalam pertumbuhan akar, memproduksi siderophore untuk meningkatkan ketersediaan dan penyerapan nutrisi di dalam tanah (Damam et al. 2016). Peneliti tersebut juga membuktikan bahwa mekanisme induksi metabolit tersebut terjadi karena adanya kontak $T$. harzianum menuju ke akar tanaman, kemudian mengkolonisasi akar dan masuk ke dalam epidermis akar tanpa merusak dinding sel. Cendawan tersebut kemudian berkembang ke daerah korteks akar melalui interseluler sel.

\section{KESIMPULAN}

Berdasarkan hasil penelitian dan pembahasan yang telah dilakukam dapat disimpulkan bahwa :

Kompetisi Agens Hayati Streptomyces sp., Gliocladium sp., dan Trichoderma harzianum terahadap Fusarium oxysporum f.sp. lycopersici pada akar tanaman tomat adalah kompetisi ruang dan nutrisi. Campuran agens hayati Streptomyces sp., Gliocladium sp., dan Trichoderma harzianum dapat menginduksi dan meningkatkan berat akar.

\section{UCAPAN TERIMA KASIH}

Ucapan terima kasih penulis sampaikan kepada Direktorat kementrian Pendidikan tinggi dan Kebudayaan yang telah memberikan bantuan dana Penelitian Hibah Bersaing 2009.

\section{DAFTAR PUSTAKA}

Akladious, SA, \& Abbas SM. 2012. Application of Trichoderma harziunum T22 as a biofertilizer supporting maize growth. African Journal of Biotechnology. 11(35): 8672-8683.

https://doi.org/10.5897/ajb11.4323

Anitha A. \& Rabeeth M. 2009. Control of Fusarium Wilt of tomato by bioformulation of Streptomyces griseus in green house condition. African Journal of Basic \& Applied Sciences. 1(2): 9-14.

Laila AF, Suryaminarsih P, \& Juliadi KSM. 2016. Penyalutan benih tomat dengan agens hayati Trichoderma sp. dan Streptomyces sp. untuk pencegahan penyakit layu fusarium (Fusarium sp.). Plumula. 5(1): 86-98. Retrieved from http://ejournal.upnjatim.ac.id/index.php/plum ula/article/view/782/656

Damam M, Moinuddin MK, \& Kausar R. 2016. Isolation and screening of plant growth promoting actinomycetes from rhizosphere of some forest medicinal plants. International Journal of ChemTech Research. 9(5): 521528.

Kamal R, Gusain YS, Kumar V, \& Sharma AK. 2015. Disease management through biological control agents: An eco-friendly and cost effective approach for sustainable agriculture- A Review. Agricultural Reviews. 36(1): 37-45. https://doi.org/10.5958/09760741.2015.00004.5

Larkin RP \& Fravel DR. 1998. Efficacy of various fungal and bacterial biocontrol organisms for control of fusarium wilt of tomato. Plant Disease, 82(9): 1022-1028. https://doi.org/ 10.1094/PDIS.1998.82.9.1022

Martínez-Medina A, Del Mar Alguacil M, Pascual J A \& Van Wees SCM. 2014. Phytohormone Profiles Induced by Trichoderma Isolates Correspond with Their Biocontrol and Plant Growth-Promoting Activity on Melon Plants. Journal of Chemical Ecology, 40(7), 804815. https://doi.org/10.1007/s10886-0140478-1

Olivain C, Humbert C, Nahalkova J, Fatehi J, L'Haridon F, \& Alabouvette C. 2006. Colonization of tomato root by pathogenic and nonpathogenic Fusarium oxysporum strains inoculated together and separately into the soil. Applied and Environmental Microbiology, 72(2): 1523-1531. https://doi.org/10.1128/ AEM.72.2.15231531.2006

Suryaminarsih P, Kusriningrum, Ni'matuzaroh, \& Surtiningsih T. 2015. Antagonistic compatibility of Streptomyces griseorubens, Gliocladium virens, and Trichoderma harzianum Againts Fusarium oxysporum cause of tomato wilt deseases. International Journal of Plant \& Soil Science. 5(2): 82-89. https://doi.org/10.9734/ ijpss/2015/11026

Tamreihao K, Ningthoujam DS, Nimaichand S, Singh ES, Reena P, Singh SH, \& Nongthomba U. 2016. Biocontrol and plant growth promoting activities of a Streptomyces corchorusii strain UCR3-16 and preparation of powder formulation for application as biofertilizer agents for rice plant. Microbiological Research. 192: 260-270. https://doi.org/10.1016/ j.micres.2016.08.005

Yedidia I, Benhamou N, \& Chet I. 1999. Induction of defense responses in cucumber plants (Cucumis sativus L.) by the Biocontrol agent Trichoderma harzianum. Applied and Environmental Microbiology. 65(3): 10611070.

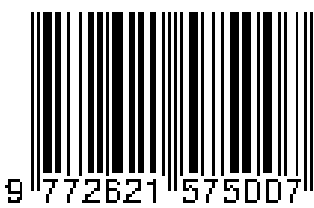

